\title{
Ehrlichia spp. infection in domestic cats from Rio de Janeiro State, southeast Brazil
}

\author{
Infecção de Ehrlichia spp. em gatos domésticos da Grande Rio de Janeiro, sudeste do Brasil \\ Andresa Guimarães ${ }^{1}$; Juliana Macedo Raimundoㄹ ${ }^{1}$ Raisa Braul Rodrigues ${ }^{2}$; Maristela Peckle Peixoto ${ }^{3}$; \\ Huarrisson Azevedo Santos ${ }^{3}$; Marcos Rogério André ${ }^{4}$; Rosangela Zacarias Machado ${ }^{4}$; Cristiane Divan Baldani ${ }^{1}$ \\ ${ }^{1}$ Departamento de Medicina e Cirurgia Veterinária, Instituto de Veterinária, Universidade Federal Rural do Rio de Janeiro - UFRRJ, \\ Seropédica, RJ, Brasil \\ ${ }^{2}$ Residente em Medicina Veterinária, Universidade Federal Fluminense - UFF, Niterói RJ, Brasil \\ ${ }^{3}$ Departamento de Epidemiologia e Saúde Pública, Instituto de Veterinária, Universidade Federal Rural do Rio de Janeiro - UFRRJ, \\ Seropédica, RJ, Brasil \\ ${ }^{4}$ Departamento de Patologia Veterinária, Faculdade de Ciências Agrárias e Veterinárias - FCAV, Universidade Estadual Paulista - \\ UNESP, Jaboticabal, SP, Brasil
}

Received August 29, 2018

Accepted October 10, 2018

\begin{abstract}
Ehrlichiosis is caused by agents belonging to Ehrlichia genus. Despite the frequent reports on the serological and molecular detection of E. canis in dogs in Brazil, there is scant data on ehrlichiosis in brazilian cats. This study aimed at investigating the occurrence of Ehrlichia spp. in domestic cats from Greater Rio de Janeiro, and evaluating hematological changes associated with this rickettsial infection. We searched for IgG antibodies against E. canis on blood samples of 216 cats by Indirect Fluorescence Assay (IFA). Additionally, we performed nested PCR (nPCR) and real-time PCR (qPCR) assays targeting E. canis-16S rRNA and $d s b$ gene, respectively. Fifty-seven (26.4\%) cats were seropositive for Ehrlichia spp. by IFA. Ehrlichia spp.-16S rRNA gene fragments were detected in 3 cats (1.4\%). Although the obtained 16S rRNA sequences showed 99 to $100 \%$ identity with E. canis, cats were negative in qPCR. Anemia, thrombocytopenia, leukocytosis, left shift neutrophil and hyperproteinemia were observed. Anemia was statistically associated with seropositivity to E. canis and kittens showed lower positivity rates $(\mathrm{p}<0.05)$. This study showed that Ehrlichia spp. occur in domestic cats from Greater Rio de Janeiro. Further studies involving culture isolation are much needed to more precisely characterize these organisms.
\end{abstract}

Keywords: Feline, nested PCR, IFA, hematology, ehrlichiosis.

\section{Resumo}

A erliquiose é causada por agentes pertencentes ao gênero Ehrlichia. Apesar dos frequentes relatos de detecção sorológica e molecular de E. canis em cães no Brasil, existem poucos dados sobre a erliquiose em gatos brasileiros. Este estudo teve como objetivo investigar a ocorrência de Ehrlichia spp. em gatos domésticos do Grande Rio de Janeiro e avaliar as alteraçóes hematológicas associadas a essa infecção rickettsial. Procuramos anticorpos IgG anti-E. canis em amostras de sangue de 216 gatos por Reação de Imunofluorescência Indireta (RIFI). Além disso, foram realizados ensaios de nested PCR (nPCR) e PCR em tempo real (qPCR) para detecção dos genes E. canis-16S rRNA e dsb, respectivamente. Cinquenta e sete (26,4\%) gatos foram soropositivos para Ehrlichia spp. pela RIFI. Fragmentos do gene rRNA de Ehrlichia spp.-16S foram detectados em 3 gatos $(1,4 \%)$ por ensaios de nPCR. Embora as sequências $16 \mathrm{~S}$ rRNA obtidas tenham 99 a $100 \%$ de identidade com E. canis, os gatos foram negativos nos ensaios de qPCR. Anemia, trombocitopenia, leucocitose, desvio nuclear neutrofílico à esquerda e hiperproteinemia foram observados. Anemia foi estatisticamente associada à soropositividade para $E$. canis e filhotes apresentaram menores taxas de positividade $(\mathrm{p}<0,05)$. Este estudo demonstra que Ehrlichia spp. ocorrem em gatos domésticos da Grande Rio de Janeiro. Outros estudos envolvendo o isolamento por cultura são necessários para caracterizar com mais precisão esses organismos.

Palavras-chave: Felino, nested PCR, RIFI, hematologia, erliquiose.

*Corresponding author: Cristiane Divan Baldani. Departamento de Medicina e Cirurgia Veterinária, Instituto de Veterinária, Universidade Federal Rural do Rio de Janeiro - UFRRJ, Rod. BR 465, Km 47, CEP 23890-000, Seropédica, RJ, Brasil. e-mail: crisbaldani@gmail.com 
Canine monocytic ehrlichiosis, caused mainly by Ehrlichia canis, has been recognized as an important infectious disease of dogs worldwide. Recently, there has been a surge of Ehrlichia spp. as a significant vector-borne agent in cats in some areas of the world, such as the United States of America (BREITSCHWERDT et al., 2002), Brazil (BRAGA et al., 2012, 2013; ANDRÉ et al., 2015; 2017), Portugal (MAIA et al., 2014), and Angola (OLIVEIRA et al., 2018).

Clinical signs and laboratory abnormalities observed in cats infected with $E$. canis include fever, lethargy, anorexia, pale mucous membranes, lymphadenopathy, splenomegaly, anemia, thrombocytopenia, leukopenia, increased serum activity of transaminases and alkaline phosphatase, and hypergammaglobulinemia (ALMOSNY \& MASSARD, 1999; STUBBS et al., 2000).

Despite the importance of this disease to cats, to date the vectors of feline ehrlichiosis are unknown. In Brazil, there are few published reports on ehrlichial infection in cats. Ehrlichia spp. have been detected by serological and/or molecular techniques in blood samples of cats from the States of Minas Gerais (OLIVEIRA et al., 2009), Maranhão (BRAGA et al., 2012), and Mato Grosso (BRAGA et al., 2013, 2017) and Rio Grande do Norte (ANDRÉ et al., 2017). Furthermore, new genotypes of Ehrlichia spp. circulating among wild felids kept in captivity in Brazilian zoos have been described (ANDRÉ et al., 2010; ANDRÉ et al., 2012).

Otherwise, very little is known about the presence of ehrlichiosis-based pathogens in Brazilian cats (BRAGA et al., 2012). Although dogs and cats may harbor a variety of parasitic agents, information on their distribution and epidemiology is still fragmented (DANTAS-TORRES \& OTRANTO, 2014).

The present study aimed at investigating the occurrence and prevalence of Ehrlichia spp. infection in domestic cats from Rio de Janeiro state, southeast Brazil, using serological and molecular techniques, and evaluate hematologic changes associated with this rickettsial disease.

A total of 216 blood samples were collected from domestic cats referred to veterinary clinics located in the metropolitan area of the State of Rio de Janeiro (Greater Rio de Janeiro), including the cities of Duque de Caxias $(n=14)$, Rio de Janeiro ( $\mathrm{n}=99)$, Nova Iguaçu $(\mathrm{n}=39)$, Belford Roxo $(\mathrm{n}=8)$, São João de Meriti $(n=21)$, and Mesquita $(n=35)$. Sampling was performed according to the availability and consent of the owners of these animals. The research proposal for this study was approved by the Committee on Animal Research and Ethics of the Universidade Federal Rural do Rio de Janeiro (UFRRJ), Seropédica, RJ, Brazil (protocol no. 23083004088/2013-94).

Blood was collected by venipuncture for hematological, serological and molecular assays. At the time of blood collection, information about the sampled animals, including gender, breed, and age, was recorded.

Hematological analyses were performed on a Poch-100iv hematology analyser (Roche, USA). Blood smears were stained with a Panoptic stain (Laborclin) and examined under a light microscope to specific leucometry. Reference values were adopted from Weiss \& Wardrop (2010).

The searching for antibodies to Ehrlichia spp. in cats' serum samples was performed using Indirect Fluorescent Antibody Test (IFA), as previously described by André et al. (2010), with a cut-off point of 1:64. Antigen was obtained from culture of DH82 cells (derived from canine histiocytoma) infected with $E$. canis (Jaboticabal strain), isolated from a Weimaraner dog, in the acute phase of the disease (AGUIAR et al., 2007). Commercial anti-cat IgG conjugated with fluorescein isothiocyanate (Sigma-Aldrich, USA) was used at a dilution of 1:32.

DNA was extracted from $200 \mu \mathrm{L}$ of EDTA whole blood from sampled cats, using the ReliaPrep ${ }^{\text {тM }}$ Blood gDNA Miniprep System (Promega $^{\mathrm{TM}}$, Madison, Wisconsin, United States), in accordance with the manufacturers instructions. Each sample of extracted DNA was used as a template in a nested PCR assay (nPCR) and real-time PCR (qPCR) for E. canis targeting $16 \mathrm{~S}$ rRNA (358 bp) (MURPHY et al., 1998) $d s b$ (378 bp) (DOYLE et al., 2005) genes, respectively. A positive DNA control for Ehrlichia canis was obtained from a dog that had been experimentally infected with the Jaboticabal E. canis strain. Ultra-pure sterile water was used as the negative control.

The positive PCR products were purified using QIA EXII Gel Extraction Kit $\left(\right.$ Qiagen $\left.^{\mathrm{TM}}\right)$ and cloned into pGEM-T Easy Vector System I (Promega Corporation ${ }^{\mathrm{TM}}$ ). Purified PCR-amplified $16 \mathrm{~S}$ rRNA inserts were sequenced using the BigDye Terminator v3.1 Cycle Sequencing Kit and ABI PRISM 310 DNA Analyzer (Applied Biosystems ${ }^{\circ}$ ). Consensus sequences were obtained through the analysis of the sense and antisense sequences using the BioEdit program (HALL, 1999).

The obtained 16S rRNA sequences were compared with sequences previously deposited in GenBank using the basic local alignment search tool (BLAST) (ALTSCHUL et al., 1990). The sequences were aligned with the sequences published in GenBank using Clustal/W (THOMPSON et al., 1994). MEGA Software (KUMAR et al., 2004) was used for phylogenetic analysis. The distance neighbor-joining method was used to build the phylogenetic tree (SAITOU \& NEI, 1987) with a Kimura 2-parameter model. The bootstrap test with 1000 replications was used to estimate the confidence of branching patterns of the neighbor-joining tree (FELSENSTEIN, 1985).

Data collected from an epidemiological questionnaire were evaluated in order to estimate possible associations between gender, breed, age, and hematological changes and the presence of ehrlichial DNA or antibodies against Ehrlichia spp. All the data were evaluated by the Chi-square test $\left(\chi^{2}\right)$ or Fisher's exact test at the $5 \%$ level of significance. Association among variables and occurrence of seropositives were estimated from values obtained by the odds ratio (OR), a confident interval at 95\%. Statistical analyses were done using the software BioEstat 5.0 (AYRES, 2000).

In the present study, IgG antibodies against $E$. canis were detected in 57 (26.4\%) domestic cats. In Brazil, a lower seropositivity rate was found by Braga et al. (2012) in the State of Maranhão, which reported $5.5 \%(11 / 200)$ of seropositive animals using the same protocol and cutoff values for IFA that were used in our study. On the other hand, the seropositivity rate for Ehrlichia found in the present study was lower than that found in cats from a semiarid region of northeast Brazil (35,6\%; 36/101) (FONTALVO et al., 2016). Ortuño et al. (2005) reported similar results among stray cats from urban areas in Barcelona, Spain, where 17.9\% (42/235) of animals showed to be seropositive for Ehrlichia spp.. On the other hand, Aguirre et al. (2004) reported a lower seroprevalence 
(10.6\%; 13/122) to Ehrlichia sp. among domestic cats in Madrid, Spain .

The differences in frequency of seropositivity for Ehrlichia reported in a number of studies conducted in Brazil and elsewhere around the globe are probably associated with a number of factors, including: the distribution of the vectors; the climate of the geographic region where the studies were carried out; the seasonal patterns exhibited by the vectors; the number of samples tested; the population studied; the presence or absence of factors associated with the habitat of these animals, such as contact with other animals, presence of ectoparasites, and outdoor access; limitations of the diagnostic technique used; and the quality of the used antigen.

Out of 216 sampled cats, while all were negative in qPCR assays for $E$. canis based on $d s b$ gene, 3 (1.4\%) were positive for nPCR assays for Ehrlichia spp. based on $16 \mathrm{~S}$ rRNA gene (2 adult males and one senior female). The analysis on 3 sequenced products based on the 16S rRNA region (GenBank accession numbers MH234590, MH234591 and MH234592) showed 99 to $100 \%$ identity with E. canis (Figure 1). In this survey, Ehrlichia spp. 16S rRNA gene fragments were from the same clade as Ehrlichia canis Oklahoma strain - which is considered the E. canis type strain - and E. canis sequences of cats from the State of Maranhão, northeast Brazil (BRAGA et al., 2012), and Taiwan.

The frequency of cats showing positive results in 16S rRNA-nested PCR assays for Ehrlichia spp. in the present study (1.4\%) was similar to that observed by Braga et al. (2012), who reported positivity rate of $1 \%(2 / 200)$ among cats tested in the State of Maranhão, northeastern Brazil. Additionally, Ehrlichia sp. 16S rRNA sequences detected in the present study were in the same clade as those sequences detected in cats from the State of Maranhão. Similarly, Tabar et al. (2008) observed a positivity rate of 1\% (1/100) in PCR assays for the genera EhrlichialAnaplasma in cats from Barcelona, Spain. On the other hand, Malheiros et al. (2016) in the State of Rio Grande do Sul, southern Brazil, and André et al. (2014) in the State of São Paulo, southeastern Brazil found no positive cases in the animals tested for this pathogen.

Among the three positive animals in the nPCR, only one was positive in the IFA. The positive result in both tests leads to the assumption that these animals were possibly in the acute or asymptomatic phase of the infection, corresponding to the period of seroconversion. Other potential hypothesis is that these animals would be through a period of resurgence as a result of immunosuppression (BRAGA et al., 2014). Negative PCR results in seropositive cats show the lack of $E$. canis in peripheral blood, during subclinical or chronic phases of the disease, despite their presence in spleen or other lymphoid tissue (EBERHARDT et al., 2006). On the other hand, the two animals positive in PCR but negative in IFA probably were facing a recent infection, when the immune system has not yet produced antibodies against the organism (VIEIRA et al., 2011).

Association between hematological findings with positive results in IFA for Ehrlichia spp. are presented in Table 1. PCR results and hematological parameters were not subjected to statistical analysis due to the small amount of data available. The most common findings

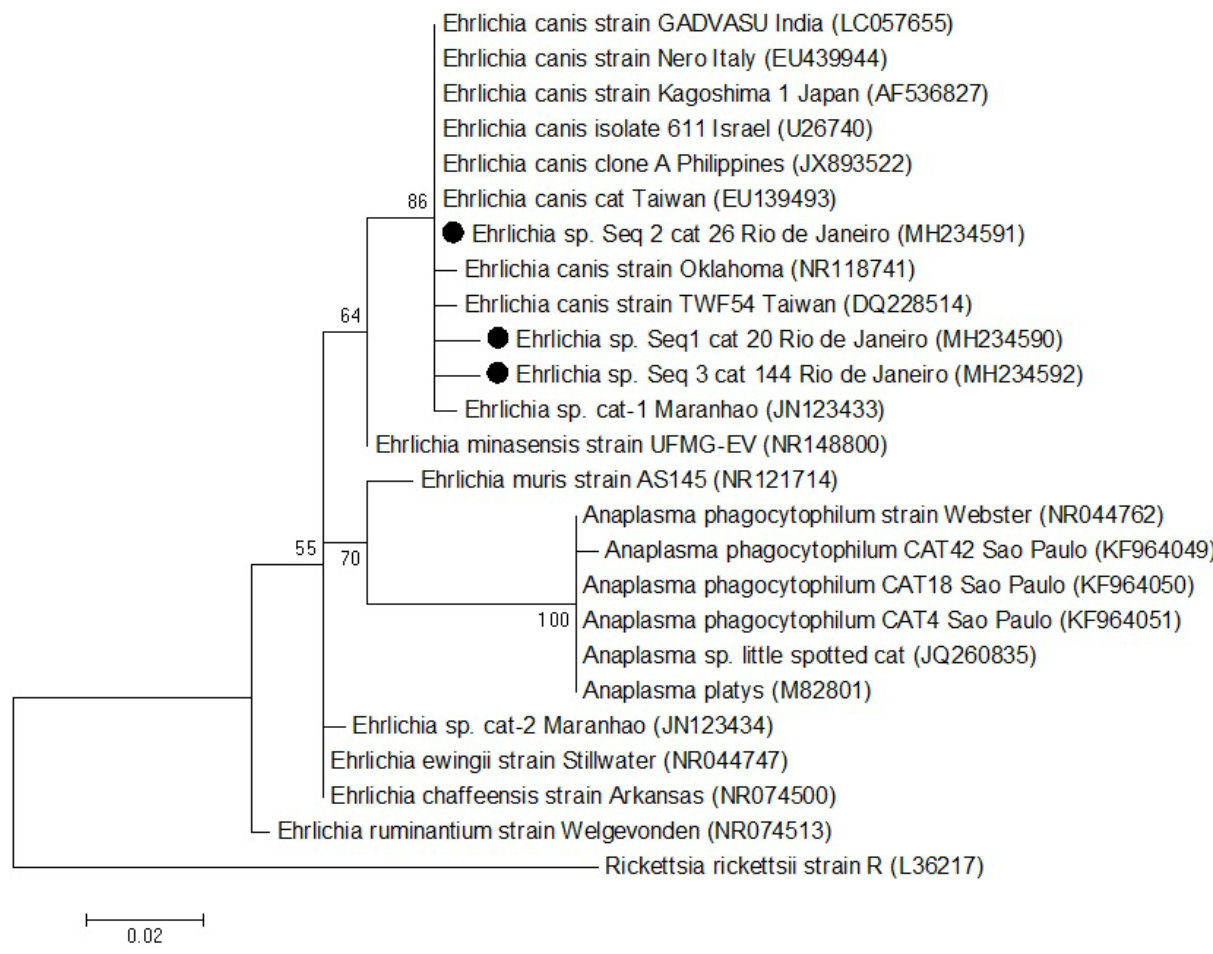

Figure 1. Phylogenetic position of Ehrlichia sp. isolates from Brazilian domestic cats from Greater Rio de Janeiro, Brazil, based on 16S rRNA sequences $(300 \mathrm{bp})$. The tree was constructed using the neighbor-joining method and the numbers on the tree indicate bootstrap values for the branch points. Accession numbers and place of origin of the isolates are shown beside the sequence names. 
in IFA and nPCR positive cats were anemia, thrombocytopenia, leukocytosis, left shift neutrophil and hyperproteinemia.

Anemia was the only hematological disorder associated with seropositive animals $(P<0.05)$, which was also observed in PCR positive animals. Indeed, anemia is frequently observed in feline and canine ehrlichiosis (BRAGA et al., 2013; DAGNONE et al., 2003; BREITSCHWERDT et al., 2002). In the present study, a normocytic normochromic anemia was often seen, which is the most common hematological abnormality in cases of natural and experimental ehrlichiosis of dogs and may be present since the first week post-infection (CASTRO et al, 2004; SILVA, 2001).

The evaluation of the seropositive cats indicated that most of them presented thrombocytopenia, and were PCR positive. Although results were not statistically confirmed, thrombocytopenia is a disorder consistent with several studies (BRAGA et al., 2013; DAGNONE et al., 2003; HARRUS et al., 1996) and appears to be the result of megakaryocytic hypoplasia and reduced platelet life span, probably due to immune-mediated inflammatory mechanisms (HARRUS et al., 1996). However, other factors must be considered as differential diagnoses of feline ehrlichiosis, such as autoimmune diseases, metastatic or hematologic malignancies and infectious diseases (FeLV and FIV).

Hyperproteinemia was also a common finding in seropositive cats and was also observed in a PCR positive animal, which is consistent with the findings of Harrus et al. (1996). In canine ehrlichiosis, hyperproteinemia is attributed to the increase of gamma globulins concentration during the febrile stage and persistence during subclinical and chronic stages of the disease (RISTIC \& HOLLAND, 1993). It is important to emphasize that animals from our study were patients referred to veterinary clinics. Therefore, hematological findings found in positive and negative cats for Ehrlichia may have been caused by other concurrent diseases and coinfections.

Table 1. Association between the results obtained by Indirect Fluorescence Assay (IFA) and frequent hematological findings in blood samples positive for E. canis from domestic cats in the metropolitan region of the State of Rio de Janeiro, southeast Brazil.

\begin{tabular}{|c|c|c|c|c|c|}
\hline \multirow{2}{*}{ Test } & \multicolumn{5}{|c|}{ IFA } \\
\hline & Positive & Negative & P value & Odds ratio & IC $(95 \%)$ OR \\
\hline $\begin{array}{l}\text { Hematological } \\
\text { parameter }\end{array}$ & 57 & 159 & & & \\
\hline Anemia & $\begin{array}{c}46^{\mathrm{a}} \\
(80.7 \%)\end{array}$ & $\begin{array}{c}30^{\mathrm{b} *} \\
(18.9 \%)\end{array}$ & 0.01 & 4.28 & $3.02 \leq \mathrm{OR} \leq 6.05$ \\
\hline Eosinophilia & $\begin{array}{c}18^{\mathrm{a}} \\
(31.6 \%)\end{array}$ & $\begin{array}{c}49^{a^{*}} \\
(30.8 \%)\end{array}$ & 0.10 & 1.02 & $0.66 \leq \mathrm{OR} \leq 1.60$ \\
\hline Hyperproteinemia & $\begin{array}{c}27^{\mathrm{a}} \\
(47.4 \%)\end{array}$ & $\begin{array}{c}60^{a^{*}} \\
(37.7 \%)\end{array}$ & 0.20 & 1.26 & $0.89 \leq \mathrm{OR} \leq 1.76$ \\
\hline Leukocytosis & $\begin{array}{c}17^{a^{*}} \\
(29.8 \%)\end{array}$ & $\begin{array}{c}70^{\mathrm{a}} \\
(44.0 \%)\end{array}$ & 0.06 & 1.48 & $0.96 \leq \mathrm{OR} \leq 2.28$ \\
\hline Lymphocytosis & $\begin{array}{c}6^{\mathrm{a}^{*}} \\
(10.5 \%)\end{array}$ & $\begin{array}{c}25^{\mathrm{a}} \\
(15.7 \%)\end{array}$ & 0.30 & 1.49 & $0.65 \leq \mathrm{OR} \leq 3.45$ \\
\hline Neutrophil Left Shift & $\begin{array}{c}32^{\mathrm{a}^{*}} \\
(56.1 \%)\end{array}$ & $\begin{array}{c}90^{\mathrm{a}} \\
(56.6 \%)\end{array}$ & 0.10 & 1.01 & $0.77 \leq \mathrm{OR} \leq 1.32$ \\
\hline Neutrophilia & $\begin{array}{c}19^{\mathrm{a}^{*}} \\
(33.3 \%)\end{array}$ & $\begin{array}{c}61^{\mathrm{a}} \\
(38.4 \%)\end{array}$ & 0.50 & 1.15 & $0.76 \leq \mathrm{OR} \leq 1.75$ \\
\hline Thrombocytopenia & $\begin{array}{c}29^{\mathrm{a}} \\
(50.9 \%)\end{array}$ & $\begin{array}{c}77^{\mathrm{a} *} \\
(48.4 \%)\end{array}$ & 0.80 & 1.05 & $0.78 \leq \mathrm{OR} \leq 1.42$ \\
\hline
\end{tabular}

$\mathrm{N}$ : number of domestic cats; IFA: Indirect Immunofluorescence Assay. Values followed by the same letter in the same line do not differ significantly ( $\mathrm{p}>0.05)$ by chi-square test. ${ }^{*}$ Odds Ratio $=1.00$.

Table 2. Association between data on gender, breed, and age with the results of Indirect Fluorescence Assay (IFA) for Ehrlichia sp.

\begin{tabular}{|c|c|c|c|c|c|c|}
\hline & & Test & IFA $E$. canis & P value & Odds ratio & IC (95\%) OR \\
\hline & & $\mathrm{N}$ & 57 & & & \\
\hline \multirow{3}{*}{ Gender } & Female & 119 & $32^{\mathrm{a}}(26.9 \%)$ & 0.97 & 1.04 & $0.67 \leq \mathrm{OR} \leq 1.64$ \\
\hline & Male & 97 & $25^{\mathrm{a}^{*}}(25.8 \%)$ & & & \\
\hline & Young & 55 & $8^{b *}(14.5 \%)$ & & & \\
\hline \multirow{3}{*}{$\mathrm{Age}^{\S}$} & Adult & 87 & $29^{a}(33.3 \%)$ & 0.02 & 2.29 & $1.13 \leq \mathrm{OR} \leq 4.64$ \\
\hline & Geriatric & 46 & $13^{\mathrm{ab}}(28.3 \%)$ & 0.14 & 1.94 & $0.88 \leq \mathrm{OR} \leq 4.28$ \\
\hline & NI & 28 & $7^{\mathrm{ab}}(25.0 \%)$ & 0.38 & 1.72 & $0.69 \leq \mathrm{OR} \leq 4.26$ \\
\hline \multirow{3}{*}{ Breed } & Crossbreed & 183 & $46^{\mathrm{a}}(25.1 \%)$ & 1.00 & 1.51 & $0.25 \leq \mathrm{OR} \leq 9.18$ \\
\hline & Purebred & 27 & $10^{\mathrm{a}}(37.0 \%)$ & 0.63 & 2.22 & $0.35 \leq \mathrm{OR} \leq 14.21$ \\
\hline & NI & 6 & $1^{\mathrm{a}^{*}}(16.7 \%)$ & & & \\
\hline
\end{tabular}

${ }^{\S}$ Young 0 to 12 months (ORTUÑO et al., 2005), adults 13-84 months and older over 85 months. NI: no information. Values followed by the same letter in the same column do not differ significantly $(\mathrm{p}>0.05)$ by chi-square test. ${ }^{*}$ Odds Ratio $=1.00$. 
Potential associations between gender, breed, and age related and positive results for Ehrlichia spp. on IFA were investigated. Age was the only variable that showed differences at 5\% significance (Table 2). Kittens showed lower positivity rates in comparison with adult cats and older (geriatric) cats. This result suggests that the animal, while still young, has limited contact with the vectors and the pathogen, and therefore has not yet developed immunity to the organism as it occurs in older animals (BANETH et al., 1998). The high frequency of positive adult cats was also reported in cats from the semiarid region of Northeast of Brazil and could be explained by the longer time of exposure to the involved vectors (FONTALVO et al., 2016).

Although attempts to amplify target genes other than $16 \mathrm{~S}$ rRNA were performed, negative results in qPCR assays based on $d s b$ gene, precluded additional inferences on the molecular identity of the ehrlichial agent circulating in cats in the state of Rio de Janeiro. On the other hand, André et al. (2015) amplified both $16 \mathrm{~S}$ rRNA and $d s b$ genes of the ehrlichial agent detected in cats sampled in Campo Grande, state of Mato Grosso do Sul, central-western Brazil, showing that E. canis or, at least, a very closely related organism may infect cats in Brazil. Future studies aiming at isolating this organism in mammalian or embryonic-tick cell lines are much needed, in order to perform a more accurate antigenic and molecular characterization of this agent. Besides, the real clinical significance of the infection by this agent in cats should be further addressed.

It is worth mentioning that, despite the fact that there is plenty of information on canine ehrlichiosis, data on Brazilian strains and the disease in cats are scarce. Therefore, further detection and genetic sequencing of Ehrlichia species from multiple areas in Brazil, as well as culture isolation are needed to more precisely characterize this organism, its geographic distribution, prevalence, new hosts, reservoirs, and zoonotic potential.

\section{Acknowledgements}

The authors are grateful to the Coordination for the Improvement of Higher Education Personnel (CAPES) that provided financial support. Author Disclosure Statement There are no competing financial interests.

\section{References}

Aguiar DM, Saito TB, Hagiwara MK, Machado RZ, Labruna MB. Serological diagnosis of canine monocytic ehrlichiosis with Brazilian antigen of Ehrlichia canis. Cienc Rural 2007; 37(3): 796-802. http:// dx.doi.org/10.1590/S0103-84782007000300030.

Aguirre E, Tesouro MA, Amusategui I, Rodriguez-Franco F, Sainz A. Assessment of feline ehrlichiosis in Central Spain using serology and a polymerase chain reaction technique. Ann N Y Acad Sci 2004; 1026(1): 103-105. http://dx.doi.org/10.1196/annals.1307.013. PMid:15604476.

Almosny NRP, Massard CL. Erliquiose felina - revisão. Clín Vet 1999; 4(23): 30-32.
Altschul SF, Gish W, Miller W, Myers EW, Lipman DJ. Basic local alignment search tool. J Mol Biol 1990; 215(3): 403-410. http://dx.doi. org/10.1016/S0022-2836(05)80360-2. PMid:2231712.

André MR, Adania CH, Machado RZ, Allegretti SM, Felippe PAN, Silva $\mathrm{KF}$, et al. Molecular and sorologic detection of Ehrlichia spp. in endangered brazilian wild captive felids. JWildl Dis 2010; 46(3): 1017-1023. http:// dx.doi.org/10.7589/0090-3558-46.3.1017. PMid:20688716.

André MR, Baccarim Denardi NC, Marques de Sousa KC, Gonçalves LR, Henrique PC, Grosse Rossi Ontivero CR, et al. Arthropod-borne pathogens circulating in free-roaming domestic cats in a zoo environment in Brazil. Ticks Tick Borne Dis 2014; 5(5): 545-551. http://dx.doi. org/10.1016/j.ttbdis.2014.03.011. PMid:24889035.

André MR, Dumler JS, Scorpio DG, Teixeira RHF, Allegretti SM, Machado RZ. Molecular detection of tick-borne bacterial agents in Brazilian and exotic captive carnivores. Ticks Tick Borne Dis 2012; 3(4): 247-253. http:// dx.doi.org/10.1016/j.ttbdis.2012.04.002. PMid:22749737.

André MR, Filgueira KD, Calchi AC, Sousa KCM, Gonçalves LR, Medeiros VB, et al. Co-infection with arthropod-borne pathogens in domestic cats. Rev Bras Parasitol Vet 2017; 26(4): 525-531. http://dx.doi. org/10.1590/s1984-29612017064. PMid:29160357.

André MR, Herrera HM, Fernandes SJ, Sousa KC, Gonçalves LR, Domingos $\mathrm{IH}$, et al. Tick-borne agents in domesticated and stray cats from the city of Campo Grande, state of Mato Grosso do Sul, midwestern Brazil. Ticks Tick Borne Dis 2015; 6(6): 779-786. http://dx.doi.org/10.1016/j. ttbdis.2015.07.004. PMid:26187416.

Ayres M. BioEstat 2.0 - Aplicaçōes Estatísticas nas Áreas das Ciências Biológicas e Médicas. Tefé: Sociedade Civil Mamirauá; 2000. 272 p.

Baneth G, Aroch I, Tal N, Harrus S. Hepatozoon species infection in domestic cats: a retrospective study. Vet Parasitol 1998; 79(2): 123-133. http://dx.doi.org/10.1016/S0304-4017(98)00160-5. PMid:9806492.

Braga IA, Santos LG, Melo AL, Jaune FW, Ziliani TF, Girardi AF, et al. Hematological values associated to the serological and molecular diagnostic in cats suspected of Ehrlichia canis infection. Rev Bras Parasitol Vet 2013 22(4): 470-474. http://dx.doi.org/10.1590/S1984-29612013000400005. PMid:24473870.

Braga ÍA, Santos LG, Souza Ramos DG, Melo AL, Cruz Mestre GL, Aguiar DM. Detection of Ehrlichia canis in domestic cats in the centralwestern region of Brazil. Braz J Microbiol 2014; 45(2): 641-645. http:// dx.doi.org/10.1590/S1517-83822014000200036. PMid:25242952.

Braga ÍA, Taques IIGG, Costa JS, Dias ISO, Grontoski EC, Ziliani TF, et al. Ehrlichia canis DNA in domestic cats parasitized by Rhipicephalus sanguineus sensu lato (s.l.) ticks in Brazil - Case report. BrazJ Vet Res Anim Sci 2017; 54(4): 412-415. http://dx.doi.org/10.11606/issn.1678-4456. bjvras.2017.128222.

Braga MSCO, André MR, Freschi CR, Teixeira MCA, Machado RZ. Molecular and serological detection of Ehrlichia spp. in cats on São Luís Island, Maranhão, Brazil. Rev Bras Parasitol Vet 2012; 21(1): 37-41. http:// dx.doi.org/10.1590/S1984-29612012000100008. PMid:22534943.

Breitschwerdt EB, Abrams-Ogg ACG, Lappin MR, Bienzle D, Hancock SI, Cowan SM, et al. Molecular evidence supporting Ehrlichia canis-like infection in cats. J Vet Intern Med 2002; 16(6): 642-649. PMid:12465759.

Castro MB, Machado RZ, de Aquino LP, Alessi AC, Costa MT. Experimental acute canine monocytic ehrlichiosis: clinicopathological and immunopathological findings. Vet Parasitol 2004; 119(1): 73-86. http://dx.doi.org/10.1016/j.vetpar.2003.10.012. PMid:15036578. 
Dagnone AS, de Morais HS, Vidotto MC, Jojima FS, Vidotto O. Ehrlichiosis in anemic, thrombocytopenic, or tick-infested dogs from a hospital population in south Brazil. Vet Parasitol 2003; 117(4): 285290. http://dx.doi.org/10.1016/j.vetpar.2003.10.001. PMid:14637030.

Dantas-Torres F, Otranto D. Dogs, cats, parasites, and humans in Brazil: opening the black box. Parasit Vectors 2014; 7(1): 22. http://dx.doi. org/10.1186/1756-3305-7-22. PMid:24423244.

Doyle CK, Labruna MB, Breitschwerdt EB, Tang YW, Corstvet RE, Hegarty BC, et al. Detection of medically important Ehrlichia by quantitative multicolor Taqman real-time polymerase chain reaction of the dsb gene. J Mol Diagn 2005; 7(4): 504-510. http://dx.doi.org/10.1016/ S1525-1578(10)60581-8. PMid:16237220.

Eberhardt JM, Neal K, Shackelford T, Lappin MR. Prevalence of selected infectious disease agents in cats from Arizona.J Feline Med Surg 2006; 8(3): 164-168. http://dx.doi.org/10.1016/j.jfms.2005.12.002. PMid:16443383.

Felsenstein J. Confidence limits on phylogenies: An approach using the bootstrap. Evolution 1985; 39(4): 783-791. http://dx.doi. org/10.1111/j.1558-5646.1985.tb00420.x. PMid:28561359.

Fontalvo MC, Braga ÍA, Aguiar DM, Horta MC. Evidências sorológicas da exposição de gatos a Ehrlichia canis. Cienc Anim Bras 2016; 17(3): 418-424. http://dx.doi.org/10.1590/1089-6891v17i333845.

Hall TA. BioEdit: a user-friendly biological sequence alignment editor and analysis program for Windows 95/98/NT. Nucleic Acids Symp Ser 1999; 41: 95-98.

Harrus S, Waner T, Avidar Y, Bogin E, Peh H, Bark H. Serum protein alterations in canine ehrlichiosis. Vet Parasitol 1996; 66(3-4): 241-249. http://dx.doi.org/10.1016/S0304-4017(96)01013-8. PMid:9017886.

Kumar S, Tamura K, Nei M. MEGA3: Integrated software for molecular evolutionary genetics analysis and sequence alignment. BriefBioinform 2004; 5(2): 150-163. http://dx.doi.org/10.1093/bib/5.2.150. PMid:15260895.

Maia C, Ramos C, Coimbra M, Bastos F, Martins A, Pinto P, et al. Bacterial and protozoal agents of feline vector-borne diseases in domestic and stray cats from southern Portugal. Parasit Vectors 2014; 7(1): 115. http://dx.doi.org/10.1186/1756-3305-7-115. PMid:24655431.

Malheiros J, Costa MM, do Amaral RB, de Sousa KCM, André MR, Machado RZ, et al. Identification of vector-borne pathogens in dogs and cats from Southern Brazil. Ticks Tick Borne Dis 2016; 7(5): 893900. http://dx.doi.org/10.1016/j.ttbdis.2016.04.007. PMid:27266811.

Murphy GL, Ewing SA, Whitworth LC, Fox JC, Kocan AA. A molecular and serologic survey of Ehrlichia canis, E. chaffeensis and E. ewingii in dogs and ticks from Oklahoma. Vet Parasitol 1998; 79(4): 325-339. http://dx.doi.org/10.1016/S0304-4017(98)00179-4. PMid:9831955.

Oliveira AC, Luz MF, Granada S, Vilhena H, Nachum-Biala Y, Lopes AP, et al. Molecular detection of Anaplasma bovis, Ehrlichia canis and Hepatozoon felis in cats from Luanda, Angola. Parasit Vectors 2018; 11(1): 167. http://dx.doi.org/10.1186/s13071-018-2767-y. PMid:29554946.

Oliveira LS, Mourão LC, Oliveira KA, Matta Agostini M, Oliveira AC, Almeida MR, et al. Molecular detection of Ehrlichia canis in cats in Brazil. Clin Microbiol Infect 2009; 15(Suppl 2): 53-54. http://dx.doi. org/10.1111/j.1469-0691.2008.02175.x. PMid:19374643.

Ortuño A, Gauss CBL, Garcia F, Gutierrez JF. Serological evidence of Ehrlichia spp. exposure in cats from Northeastern Spain. J Vet Med 2005; 52(5): 246-248. http://dx.doi.org/10.1111/j.1439-0450.2005.00849.x. PMid:16115100.

Ristic M, Holland CJ. Canine ehrlichiosis. In: Woldehiwet Z, Ristic M, editors. Rickettsial and Chlamydial diseases of domestic animals. Oxford: Pergamon; 1993. p.169-186.

Saitou N, Nei M. The neighbor-joining method: A new method for reconstructing phylogenetic trees. Mol Biol Evol 1987; 4(4): 406-425. PMid:3447015.

Silva VLD. Avaliação das alteraçôes hematológicas e dos aspectos citológico e histopatológico da medula óssea, na erliquiose canina aguda: estudo experimental. [Dissertação] Faculdade de Medicina Veterinária e Zootecnia, Universidade de São Paulo, São Paulo, 2001.

Stubbs CJ, Holland CJ, Reif JS, Wheeler S, Bruns C, Lappin MR. Feline ehrlichiosis. Compend Contin Educ Vet 2000; 22(4): 307-318.

Tabar MD, Altet L, Francino O, Sánchez A, Ferrer L, Roura X. Vectorborne infections in cats: Molecular study in Barcelona area (Spain). Vet Parasitol 2008; 151(2-4): 332-336. http://dx.doi.org/10.1016/j. vetpar.2007.10.019. PMid:18079064.

Thompson JD, Higgins DG, Gibson TJ. CLUSTAL W: improving the sensitivity of progressive multiple sequence alignment through sequence weighting, position-specific gap penalties and weight matrix choice. Nucleic Acids Res 1994; 22(22): 4673-4680. http://dx.doi.org/10.1093/ nar/22.22.4673. PMid:7984417.

Vieira RFC, Biondo AW, Guimarães AMS, Santos AP, Santos RP, Dutra LH, et al. Ehrlichiosis in Brazil. Rev Bras Parasitol Vet 2011; 20(1): 1-12. http://dx.doi.org/10.1590/S1984-29612011000100002. PMid:21439224.

Weiss DJ, Wardrop KJ. Schalm's Veterinary hematology. 6th ed. Iowa: Wiley-Blackwell; 2010. 